9.

\title{
BEOGRAD KAO JUGOSLAVENSKI \\ INTERKULTURNI GRAD U \\ KONTEKSTU KULTURNE SURADNJE \\ S AFRIKOM (1961. - 1971.)
}

\section{Goran Korov}

UDK: 908(497.11 Beograd):008(6)“1961/1971“

Pregledni članak

Sažetak: U ovom se radu nastoji prikazati presjek značajnijih primjera kulturne razmjene između Beograda i pojedinih afričkih zemalja u periodu između 1961. i 1971. godine, kada se Jugoslavija profilirala kao jedna od vodećih zemalja u Pokretu nesvrstanih zemalja. Nesvrstana politika Jugoslavije prema cijelom jednom korpusu zemalja Afrike, koje su postale nezavisne od bivših kolonijalnih gospodara, omogućila joj je razvitak iznimno intenzivne suradnje na ekonomskom, tehničkom, prosvjetnom, kulturnom i ostalim poljima. U širokom spektru kulturne suradnje, u ovom se radu naglasak stavlja uglavnom na gostovanja likovnih i ostalih umjetničkih izložbi. Nakon uvoda slijedi pregled angažmana beogradskih/ srpskih/jugoslavenskih kulturnih radnika u Africi, a zatim i kulturnih manifestacija afričke provenijencije u Beogradu. U zaključku se razvoj Beograda kao interkulturnog centra Jugoslavije stavlja u kontekst sve intenzivnije suradnje i angažmana Jugoslavije u Pokretu nesvrstanih zemalja tijekom prvog desetljeća njegova postojanja.

Ključne riječi: Beograd, Jugoslavija, Afrika, Pokret nesvrstanih zemalja, kulturna suradnja, interkulturalizam, kulturna povijest, Komisija za kulturne veze s inostranstvom

\section{UVOD}

II akon razlaza sa Sovjetskim Savezom 1948., Jugoslavija se našla u političkom vakuumu, koji je nastojala ispuniti približavanjem Zapadu. Međutim, i taj je pristup ubrzo splasnuo nakon Staljinove smrti 1953. i posjeta Nikite Hruščova Beogradu. Ipak, gušenje ustanka u Mađarskoj i Sueska kriza 1956. godine definitivno su uvjerili jugoslavensko rukovodstvo da se previše ne veže uz političke blokove. Istodobno, u Aziji i Africi pokrenut je val dekolonizacije; Gana je 1957. postala prva supsaharska država Afrike koja je stekla nezavisnost. Josip Broz Tito već je u srpnju 1956., zajedno s Gamalom Abdelom Naserom i Jawaharlalom Nehruom, potpisao tzv. Brijunsku deklaraciju, koja se smatra jednom od 
ključnih inicijativa na putu do osnutka Pokreta nesvrstanih zemalja na Osnivačkoj konferenciji, održanoj u Beogradu u rujnu 1961. godine. ${ }^{1}$ Jugoslaviji se tada pružala prilika predstaviti svoj političko-ekonomski sustav i svoju kulturu tek osamostaljenim afričkim državama. Budući da su nove afričke države zazirale od bivših kolonizatora, a SSSR smatrale hegemonom svoje vrste, jugoslavensko rukovodstvo uvjerilo se da mu je ovo savršena prilika za stjecanje podrške među sasvim novim korpusom novonastalih država. Jedan od najekonomičnijih načina afirmiranja Jugoslavije bio je pokazati afričkim nacijama njezino kulturno, umjetničko i povijesno nasljeđe u vidu raznih izložbi, projekcija, predstava ili predavanja. Ovakav je „mekan“ pristup afričkim društvima naposljetku olakšavao jugoslavenskim stručnjacima i poduzećima razne poslove i projekte u mnogim afričkim i azijskim zemljama.

Slijedeći naveden kontekst, u ovom će se radu iznijeti pregled značajnijih gostovanja umjetničkih izložbi i bliskih kulturnih događaja afričke provenijencije u Beogradu, ali i izložbi umjetnika i ostalih kulturnih radnika iz Beograda te Srbije i Jugoslavije u pojedinim afričkim zemljama u razdoblju od 1961. do 1971. godine. Beograd je tako u svom kulturnom životu polagano stjecao novu komponentu, onu jednog od centara jugoslavenskog interkulturalizma. ${ }^{2} \mathrm{U}$ tom su procesu, uz Beograd, i mnoga druga mjesta u Jugoslaviji postala centrima interkulturalizma i njegovanja suradnje s Pokretom nesvrstanih. U Zagrebu je od 1963. godine djelovao Institut za proučavanje Afrike, ${ }^{3}$ u Ljubljani se afrička kultura prezentirala u Muzeju neeuropskih kultura, ${ }^{4}$ a u Titogradu (današnja Podgorica) je u sklopu Centra savremene umjetnosti bilo, a i još uvijek jest, izloženo preko tisuću eksponata iz 60 nesvrstanih zemalja. ${ }^{5}$ Otočje Brijuni bili su također jedno od tih mjesta gdje su se u službeni posjet jugoslavenskom rukovodstvu primali brojni vođe i izaslanici iz nesvrstanih zemalja.

Prije svega treba napomenuti da je u ovom radu angažman umjetnika s područja Srbije izdvojen iz zajedničkog nastupa svih umjetnika s područja Jugoslavije. Naime, umjetničke izložbe i nastupi pažljivo su se organizirali prema nacionalnom ključu, odnosno podjednakoj zastupljenosti predstavnika svih saveznih republika Jugoslavije. Tako se prezentirala kulturna raznolikost i ravnopravna zastupljenost svih naroda Jugoslavije. Ovdje je između potonje i mnogih afričkih zemalja postojala paralela jer su zbog kolonijalnih granica pojedine afričke države bile skup raznih kultura, religija i jezika.

1 Za više informacija o vanjskoj politici Jugoslavije između Informbiroa i osnutka Pokreta nesvrstanih, među ostalim, valja pogledati sljedeće: Dragan Bogetrć i Olivera Bogetić, Nastanak i razvoj pokreta nesvrstanosti, Beograd 1981., 9-38; Dušan BILandžıć, Historija Socijalističke Federativne Republike Jugoslavije: glavni procesi 1918-1985, Zagreb 1985., 139-265; Darko BeKıć, Jugoslavija u hladnom ratu: odnosi s velikim silama 1949-1955, Zagreb 1988.; D. BoGETIĆ, Nova strategija spoljne politike Jugoslavije 1956-1961, Beograd 2006.; Tvrtko JAKovinA, Tré́a strana hladnog rata, Zaprešić 2011., 31-44; Rinna KullaA, Non-Alignment And Its Origins In Cold War Europe, London - New York 2011.; Branka Doknić, Kulturna politika Jugoslavije 1946-1963, Beograd 2013.; Ivo Goldstein i Slavko GoLDSTEIN, Tito, Zagreb 2015., 511-603.

2 Događaj koji bi se mogao nazvati „krunom“ Beograda kao interkulturnog centra bilo je svakako svečano otvaranje Muzeja afričke umetnosti - zbirke Vede i dr. Zdravka Pečara 1977. godine.

3 Biserka CvjetiČAnin, „Uloga instituta za razvoj i međunarodne odnose u Pokretu nesvrstanih“, Razvojna suradnja kroz nasljecte Pokreta nesvrstanih (ur. Gordan Bosanac i Petra Jurlina), Zagreb 2015., 12.

4 Eyachew Tefera, „Iskustva razvojne suradnje Slovenije iz vremena Pokreta nesvrstanih“, Razvojna suradnja kroz nasljede Pokreta nesvrstanih 164., ur. Gordan Bosanac i Petra Jurlina.

5 Eksponate iz afričkih zemalja je za Centar od 1981. godine prikupljala i izlagala Galerija umjetnosti nesvrstanih zemalja „Josip Broz Tito“. 


\section{Manifestacije Kulturnih Radnika Beograda/Srbije u Africi}

Godina 1961. bila je iznimno bogata aktivnostima na području kulturne suradnje FNR Jugoslavije s određenim zemljama u svijetu. U prvom je planu na tom polju najviše aktivnosti pokrenula i ostvarila Komisija za kulturne veze s inostranstvom Saveznog izvršnog veća Jugoslavije. Značajan doprinos u ostvarenju i definiranju odnosa s afričkim zemljama imala je i Komisija za međunarodne odnose i veze s inostranstvom CK SKJ. Osim suradnje s europskim zemljama, uspostavljena je i proširena suradnja s većim brojem zemalja Afrike, Azije i Latinske Amerike. Ovdje valja navesti da su te godine potpisane nove kulturne konvencije s Ganom, Gvinejom, Kambodžom, Libanonom i Bolivijom, a također je zaključeno i 14 međudržavnih sporazuma o kulturnoj suradnji s Belgijom, Bugarskom, Čehoslovačkom, Grčkom, Irakom, Istočnom Njemačkom, Italijom, Mađarskom, Norveškom, Poljskom, Rumunjskom, Sovjetskim Savezom, Sudanom i Ujedinjenom Arapskom Republikom. ${ }^{6}$ Jugoslavija je i prije osnutka Pokreta nesvrstanih zemalja imala razvijene odnose s pojedinim zemljama u razvoju, još od početka 1950-ih godina - od razmjene studenata preko gostovanja izložbi ili održavanja kulturnih priredbi (npr. izložba jugoslavenske sekcije na I. Mediteranskom bijenalu, održanom 1955. u Kairu) do sudjelovanja u očuvanju nacionalnog blaga pojedinih država (UNESCO-ov projekt očuvanja i konzervacije spomenika Stare Nubije u Egiptu 1960. - 1963. godine). ${ }^{7}$

Jugoslavija i Egipat jače su se povezali posebno nakon Brijunskog sporazuma (1956.), ${ }^{8}$ kada su, zajedno s ostalim zemaljama Azije i Afrike, koje su nedavno stekle nezavisnost, krenuli putem „neangažiranja“ u podjeli na ideološke blokove (inicijativa koja će 1961. prerasti u Pokret nesvrstanih zemalja). Suradnja između dviju zemalja na kulturnom polju bazirala se na Sporazumu o kulturnoj suradnji, zaključenom 22. prosinca 1958. godine. ${ }^{9}$ Od svih suradnji na tome polju između dviju zemalja, najznačajnije je bilo sudjelovanje Jugoslavije na izložbama Mediteranskog bijenala koji se svake druge godine održavao u Aleksandriji (prvi je održan 1955. godine). Prva osnivačka konferencija Pokreta nesvrstanih zemalja u Beogradu odvijala se u rujnu 1961., ${ }^{10}$ pred otvaranje IV. Mediteranskog bijenala, koji je trajao od 14. prosinca 1961. do 31. ožujka 1962. godine. Na bijenalu su u sekciji skulptura bila izložena djela Olge Jančić, Olge Jevrić, Milana Vergovića, Jovana Kratohvila, zatim slike Šime Perića, Miće Popovića, Lazara Vujaklije, Bogoljuba Ivkovića, Vojislava Voje Stanića te člana ULU-a Slovenije Janeza Bernika. ${ }^{11}$ Prema izvještaju Saveznog izvršnog veća, sudjelovanje Jugoslavije na IV. Mediteranskom bijenalu istaknuto je kao jedna od najuspjelijih likovnih manifestacija te godine, uz bijenale u Sao Paolu i Riminiju te izložbe

6 „Kulturne veze sa inostranstvom u 1961.“, Jugoslovenski pregled (Beograd), god. 6, br. 4, april 1962., 13.

7 Arhiv Jugoslavije (dalje: AJ), Savezno izvršno veće (dalje: SIV), 3174/1./1960., kut. 647.; B. Doknić, Kulturna politika Jugoslavije 1946-1963, 301.

8 D. Bogetić i O. Bogetić, Nastanak i razvoj pokreta nesvrstanosti, 21-22.

9 „Odnosi Jugoslavije i Ujedinjene Arapske Republike“, Jugoslovenski pregled (Beograd), god. 10, br. 3, mart 1966., 27.

10 D. Bogetić, Nova strategija spoljne politike Jugoslavije 1956-1961, 368.

11 4ème Bienalle d'Alexandrie: 14 Décembre 1961 - 31 Mars 1962, katalog izložbe, Aleksandrija 1961. 
u Londonu i Parizu. Gostovanje Beogradske opere u Kairu 1961. također nije prošlo nezapaženo $^{12}$ te je, uz nastup Zagrebačke opere u okviru Teatra nacija u Parizu iste godine, istaknuto kao najznačajniji događaj u oblasti glazbene i scenske umjetnosti. ${ }^{13}$ Saveznoj komisiji za kulturne veze s inostranstvom posebno je bilo važno istaknuti se svojim izlošcima na V. Mediteranskom bijenalu u Aleksandriji jer su egipatski organizatori bijenala očekivali sudjelovanje svih mediteranskih zemalja. Osim toga, Jugoslavija se svakako morala angažirati u ovom kulturnom događaju obvezavši se u ranije potpisanom Planu o kulturnoj suradnji s Egiptom. ${ }^{14}$ Peti Mediteranski bijenale u Aleksandriji održan je od 12. prosinca 1963. do 31. ožujka 1964., a sudionici-članovi ULUS-a bili su Milivoj Nikolajević, Milan Cmelić i Branislav Protić. ${ }^{15}$ Šesti Mediteranski bijenale u Aleksandriji održan je od prosinca 1965. do ožujka 1966., a od članova ULUS-a izlagali su: Milivoj Nikolajević, Slobodan Pejović, Marko Krsmanović, Zoran Pavlović i kipar Jovan Soldatović. ${ }^{16} \mathrm{Na}$ ovom, kao i na VII. Mediteranskom bijenalu, održanom od prosinca 1967. do ožujka 1968., jugoslavenski sudionici osvojili su nekoliko nagrada. ${ }^{17}$

Jugoslavija i Sudan potpisali su Sporazum o kulturnoj suradnji 1959. godine, tri godine nakon što je ova zemlja stekla nezavisnost. Već se 1963. godine navodi kako Sudan spada među zemlje iz kojih dolazi relativno najviše stranih studenata na fakultete širom Jugoslavije. ${ }^{18}$ Osim u sferi kulture, suradnja se razvijala i na ostalim poljima. Tako je Bratislav Stojanović (1912. - 1996.), beogradski arhitekt, projektant, urbanist, slikar i grafičar, 1963. godine bio angažiran na projektiranju Kulturnog centra u Kartumu. Istovremeno su kulturni stručnjaci Sudana izrazili želju da se u Kartumu postavi Stojanovićeva izložba grafike s motivima iz Sudana, koja se početkom te godine održala u Kulturnom centru u Beogradu. ${ }^{19}$

Republika Mali izborila se za nezavisnost od Francuske 1960., ali je uspostavljanje tješnjih veza između dviju država teklo sporo. Ugovor o kulturnoj suradnji SFRJ s Malijem ipak je konačno potpisan 1963. godine. ${ }^{20}$ Iste godine već je pokrenuta inicijativa na polju suradnje. Folklorna grupa Jugokoncerta je, nakon europske i azijske turneje, trebala gostovati i u Maliju, a već u travnju 1963. Singare, izaslanik malijskog ministra kulture Keite, brata tadašnjeg predsjednika Modiba Keite, doputovao je u Beograd i potpisao ugovor o kulturnoj suradnji. Delegacija Malija također je proučila školski sustav SFRJ i zatražila osnutak Tehničke škole u Maliju u kojoj bi radilo 150 profesora koji bi držali predavanja na

12 U suradnji između dviju zemlja bila je posebno razvijena suradnja između Beogradske i Kairske opere. Beogradska opera i balet gostovali su u Kairu 1961., 1962. i 1963. godine. Tijekom sezone 1962./1963. dirigent Dušan Miladinović radio je s ansamblom Kairske opere, a pored toga je Beogradska opera primala na specijalizaciju članove Kairske opere. U simfonijskom orkestru u Kairu je od 1960. godine radilo od 7 do 10 jugoslavenskih glazbenika, a za rad s njima bio je dodijeljen dirigent Živojin Zdravković (v. „Odnosi Jugoslavije i Ujedinjene Arapske Republike“, Jugoslovenski pregled (Beograd), god. 10, br. 3, mart 1966., 27).

13 „Kulturne veze sa inostranstvom u 1961.“, Jugoslovenski pregled (Beograd), god. 6, br. 4, april 1962., 13.

14 AJ, Savezna komisija za kulturne veze s inostranstvom (dalje: SKKVI), 189/1963., kut. 60.

15 Sème Bienalle d'Alexandrie: 12 Décembre 1963 - 31 Mars 1964, katalog izložbe, Aleksandrija 1963.

16 6 Bienalle d'Alexandrie: 15 Décembre 1965 - 31 Mars 1966, katalog izložbe, Aleksandrija 1965.

17 „Odnosi Jugoslavije i Ujedinjene Arapske Republike“, Jugoslovenski pregled (Beograd), god. 13, br. 5, maj 1969., 23.

18 AJ, SKKVI, 1455/1963., kut. 60.

19 AJ, SKKVI, 1162, 1238/1963., kut. 60.

20 Kulturna politika i razvitak kulture u Hrvatskoj, Zagreb 1982., 228. 
francuskom jeziku. Izrazila je i želju da se te godine primi nekolicina studenata-stipendista iz SFRJ. ${ }^{21}$ Iste je godine u srpnju Maroko posjetila folklorna grupa Kulturno-umetničkog društva „Ivo Lola Ribar“ iz Beograda, ${ }^{22}$ a u veljači 1964. održana je izložba suvremenog jugoslavenskog slikarstva. ${ }^{23}$ Odnosi Jugoslavije s Marokom zahladnjeli su nakon listopada 1963. zbog izbijanja kratkotrajnog Pješčanog rata s Alžirom (u kome je Jugoslavija pružila potporu Alžiru), ali se do prosinca situacija smirila i odnosi su se nastavili uobičajenim ritmom. ${ }^{24}$

Tijekom 1970. godine izložba slika i grafike mladih jugoslavenskih umjetnika gostovala je u Tunisu, Rabatu i Casablanci, da bi se naposljetku održala i u Alžiru. Iz Srbije su na izložbi bila izložena djela slikarâ Tomislava Dugonjića, Živka Đaka, Dragoša KalajićaDrage i Dušana Otaševića te grafike Živka Đaka, Stevana Kneževića, Miodraga Nagornija, Milana Stanojeva i Desanke Tomić-Đurović. Na ovoj je izložbi, od sudionika iz svih saveznih republika, uvjerljivo prevladavao broj umjetnika s područja SR Srbije, odnosno članova ULUS-a. ${ }^{25}$

\section{Afričke kulturne manifestacije u Beogradu}

Jugoslavija i Etiopija su i prije osnutka Pokreta nesvrstanih zemalja imale razvijene odnose. Obje zemlje iskusile su fašističku okupaciju, a njihovi su narodi sudjelovali u pokretu otpora (Etiopija 1936. - 1941., Jugoslavija 1941. - 1945.). Car Haile Selassie bio je prvi šef neke države koji je posjetio Jugoslaviju nakon Informbiroa 1948. godine. Kipar Antun Augustinčić je u drugoj polovini 1950-ih izradio nekoliko javnih spomenika u Etiopiji (npr. Spomenik žrtvama fašizma u Addis Abebi, Spomenik Rasu Makonnenu, Spomenik etiopskom partizanu). Dvije su zemlje 17. travnja 1963. potpisale ugovor o kulturnoj suradnji, a već 21 . travnja potpisan je dvogodišnji Program kulturne suradnje između dviju zemalja. Stoga iz te godine vrijedi izdvojiti početak inicijative jugoslavenskog veleposlanstva u Addis Abebi, datirane od rujna 1963., da se u Kulturnom centru Beograda održi izložba određenog etiopskog slikara. Međutim, na zahtjev etiopskog Ministarstva kulture ta je inicijativa prerasla u skupnu izložbu više etiopskih slikara. U listopadu iste godine konačno je dogovoreno da se u Beogradu održi 18-dnevna izložba s odabranih oko 120 eksponata $s$ područja stare, prijelazne i moderne etiopske likovne umjetnosti. ${ }^{26} \mathrm{Ta}$ je izložba naposljetku održana tijekom srpnja i kolovoza 1964. godine, a osim Beograda, gostovala je i u Zagrebu i Ljubljani. ${ }^{27}$

Jugoslavija i Sudan potpisali su Sporazum o kulturnoj suradnji već 1959., tri godine nakon što je ova zemlja stekla nezavisnost. Na temelju ugovora o kulturnoj suradnji za

\footnotetext{
AJ, SKKVI, 215, 270, 417/1963., kut. 60.

22 Primjera radi, valja navesti da je folklorna grupa KUD-a „Ivo Lola Ribar“, među ostalim, održala i više priredbi po Zambiji tijekom 15-dnevne turneje u listopadu 1969. godine (v. „Odnosi Jugoslavije i Zambije“, Jugoslovenski pregled (Beograd), god. 14, br. 7/8, jul/avgust 1970., 68).

23 „Odnosi Jugoslavije i Maroka“, Jugoslovenski pregled (Beograd), god. 11, br. 3, mart 1967., 28.

24 AJ, SKKVI, 2055/1963., kut. 60.

25 L'exposition de Peinture et de Gravure des Jeunes Artistes Yougoslaves, katalog izložbe, Alžir 1970.

26 AJ, SKKVI, 1475, 1707/1963., kut. 60.

27 „Odnosi Jugoslavije i Etiopije“, Jugoslovenski pregled (Beograd), god. 10, br. 1, januar 1966., 3.
} 
1964./1965. godinu, dogovoreno je da se u Kartumu održi izložba fotografija moderne jugoslavenske arhitekture "Jugoslovenska arhitektura“ (u organizaciji Saveza arhitekata Jugoslavije), a u Beogradu izložba sudanske skulpture pod nazivom „Crnačka plastika“. Također valja istaknuti da je otprilike u vrijeme dogovaranja oko održavanja tih dviju izložbi u Kartumu održana izložba grafike arhitekta Bratislava Stojanovića (spomenuta u prethodnom poglavlju). ${ }^{28}$ Iste je godine održana i izložba jugoslavenske arhitekture u libijskom Tripoliju.

Posebno značajan događaj koji se održao 1965. godine u Beogradu, odnosno u Muzeju primenjene umetnosti, bila je izložba "Crnačka umetnost" iz Senegala, koja je gostovala i u Zagrebu, u Etnografskom muzeju, tijekom studenog iste godine. Prvoslav Mitić napisao je o ovoj izložbi sljedeće:

Izložba afričke crnačke umetnosti, koju Beograd ima prilike da vidi u drugoj polovini ovog meseca u organizaciji Komisije za kulturne veze sa inostranstvom, predstavlja po svemu izuzetan događaj. To je možda prvi ozbiljan susret publike našeg glavnog grada sa jednom umetnošću koja u našem veku sve više uzbuđuje izuzetnom i spontanom emocijom. Zbog toga treba pozdraviti napore organizatora i napore Muzeja primenjene umetnosti (...)

$\mathrm{Na}$ izložbi je bilo prikazano više od 80 izložaka koji su obuhvaćali skulpturu, maske, tekstil, nakit i ostale dekorativne predmete. Većinu eksponata za izložbu predalo je Veleposlanstvo Senegala u Beogradu, zatim Francuski institut Crne Afrike u Dakaru te veleposlanstva Republike Mali i Republike Gvineje. Prvoslav Mitić je povodom izložbe održao i predavanje o crnačkoj umjetnosti 23. rujna iste godine. ${ }^{29}$

Godinu 1965. obilježio je značajan događaj ne samo za beogradsku nego i za jugoslavensku likovnu scenu. Otvaranjem i daljnjim djelovanjem Muzeja savremene umetnosti u Novom Beogradu, međunarodne izložbe zauzimaju značajan dio izlagačkog programa ove ustanove u okviru Muzeja kao organizatora pojedinih izložbi ili kao izvršitelja obveza na osnovi konvencija o međunarodnoj razmjeni u posredstvu s Komisijom za kulturne veze s inostranstvom. ${ }^{30}$

Tunis i Jugoslavija zaključili su konvenciju o kulturnoj suradnji 1962. godine i od tada se odnosi ovih dviju zemalja iznimno razvijaju u svim oblastima. Suradnju na kulturnom polju u drugoj polovini 1960-ih obilježile su manifestacije „Nedelja kulture Tunisa“ u Jugoslaviji i „Nedelja kulture naroda Jugoslavije“ u Tunisu. ${ }^{31}$ „Nedelja kulture Tunisa“ održana je tijekom siječnja 1969. godine u Beogradu. Svečano otvorenje manifestacije održao je tuniski ministar za kulturu i informacije Chedli Klibi, a tom prigodom održana je izložba slika tuniskog slikara El Mekija, emitirali su se tuniski filmovi te je gostovao tuniski folklorni ansambl koji je, osim u Beogradu, nastupao i u još nekoliko jugoslavenskih gradova. ${ }^{32}$

28 AJ, SKKVI, Izložba „crnačka plastika“ iz Sudana, 315/1965., kut. 60.

29 AJ, SKKVI, Izložba crnačke umetnosti, 632.2-30/1965., kut. 60.

30 Ješa Denegri, „Izložbe inostrane moderne i savremene umetnosti u Srbiji“, Istorija umetnosti u Srbiji XX vek. Drugi tom: Realizmi i modernizmi oko hladnog rata (ur. Miško Šuvaković), Beograd 2012., 377.

31 „Nedelja kulture naroda Jugoslavije“ održana je u Tunisu, Bizerti, Sfaxu i Nabelu u veljači 1971. godine. Tijekom trajanja manifestacije održane su dvije izložbe, gostovanja Baleta iz Sarajeva i Orkestra iz Skoplja, te emitirani novi jugoslavenski filmovi (v. „Odnosi Jugoslavije i Tunisa 1965-1972.“, Jugoslovenski pregled (Beograd), god. 16, br. 11/12, novembar/decembar 1972., 67).

32 „Odnosi Jugoslavije i Tunisa 1965-1972.“, Jugoslovenski pregled (Beograd), god. 16, br. 11/12, novembar/decembar 1972., 67. 


\section{ZAKLJUČAK: ŠIRENJE KULTURNE SURADNJE, OTVARANJE NOVOG SVIJETA}

Jugoslavija se uključila u suradnju sa zemaljama u razvoju 1954. godine, stavivši na raspolaganje svoje stručnjake Etiopiji, a nakon toga Sudanu, Tunisu, Egiptu, Iraku, Siriji i ostalim zemljama Afrike i Azije, usporedno s njihovim stjecanjem nezavisnosti, odnosno procesom dekolonizacije. ${ }^{33}$

Sve veća suradnja SFRJ na svim poljima sa zemljama u razvoju stvarala je paralelno probleme tehničke prirode, poput neorganiziranosti, kašnjenja u izvršavanju obveza, nekompetencije većine kadrova koji su obitavali u veleposlanstvima zemalja gdje su se manifestacije održavale i ostalo. Već su početkom 1961. godine članovi Umetničkog saveta Saveza udruženja likovnih umjetnika Jugoslavije (SULUJ) na sastanku, među ostalim točkama, istaknuli potrebu za objavom jednog pravilnika:

(...) koji bi regulisao odnose između izlagača i organizatora izložbi tj. Komisije za kulturne veze s inostranstvom. Ovaj Pravilnik morao bi da obuhvati sve komponente međusobnih odnosa kao što su: obaveze izlagača, obaveze organizatora; pitanje obeštećenja oštećenih ili izgubljenih dela, rokove vraćanja autorima njihovih radova. Zatim pitanje izvođenje skulptorskih dela u materijalu izabranih za izložbu i nadoknada troškova, kao i pitanje dostavljanja informacija o toku i rezultatima izlaganja svakom izlagaču ponaosob. ${ }^{34}$

Problematiku istaknutu još 1961. na sastancima SULUJ-a dobro ilustrira dokument iz rujna 1965. godine, gdje se unutar Saveznog fonda za međunarodnu tehničku saradnju ističe kako se do tog trenutka samo u zemljama Afrike i Azije nalazi više od 800 jugoslavenskih stručnjaka. Širenje te suradnje znalo je uzrokovati i teškoće poput kašnjenja i neizvršavanja obveza uslijed nedovoljne angažiranosti i nesnalaženja diplomatsko-konzularnih predstavništava SFRJ te je na poticaj Saveznog izvršnog vijeća pri Saveznom zavodu trebalo osnovati komisije koje bi nakon javnih natječaja vršile stručan odabir kandidata za izvršavanje obveza u inozemstvu. ${ }^{35}$

U razdoblju od 1954. do 1969. godine Jugoslavija je za 32 zemlje u razvoju stavila na raspolaganje oko 3.000 svojih stručnjaka na svim poljima, a 2.600 stipendista iz 75 zemalja u razvoju završilo je školovanje u jugoslavenskim školama, dok je specijalizaciju i poslijediplomske studije završilo oko 1.000 stranih stručnjaka. Do početka 1970. godine u zemljama u razvoju djelovalo je 1.165 stručnjaka iz Jugoslavije, a oko 6.000 studenata iz tih zemalja pohađalo je u tom trenutku jugoslavenske škole o svom ili o trošku svojih zemalja. Što se tiče regionalnog razmještaja, 999 ili 85,9\% jugoslavenskih stručnjaka djelovalo je u arapskim, 156 ili 13,4\% u afričkim, 7 ili 0,6\% u azijskim te 1 ili 0,01\% u latinoameričkim zemljama. ${ }^{36}$ Beograd je, kao glavni grad Jugoslavije, većim dijelom bio polazište svih ini-

33 „Jugoslavija u međunarodnoj tehničkoj saradnji“, Jugoslovenski pregled (Beograd), god. 14, br. 6, jun 1970., 59.

34 AJ, Savez udruženja likovnih umetnika Jugoslavije (dalje: SULUJ), „ZAPISNIK vodjen 1. februara 1961 godine na sastanku (nečitko) dela Umetničkog saveta Saveza", kut. 15.

35 AJ, SIV, 1003/1965., kut. 607.

36 „Jugoslavija u međunarodnoj tehničkoj saradnji“, Jugoslovenski pregled (Beograd), god. 14, br. 6, jun 1970., 59. 
cijativa te je stoga opravdano stekao epitet jednog od interkulturnih centara zemlje, koja je kao jedna od vodećih predvodnica Pokreta nesvrstanih zemalja imala zapaženo mjesto i prepoznatljivost na svjetskoj razini.

\section{$\cos$}

\section{Belgrade as a Yugoslav Center of interculturalism IN THE CONTEXT OF THE CULTURAL EXCHANGE WITH Africa (I96I - I97I)}

After the split with the USSR in 1948, Yugoslavia was left in a political vacuum, one that it attempted to fill by getting nearer to the West. However, that approach ran out of steam after Stalin's death in 1953 and Nikita Khrushchev's visit to Belgrade. The repression of the Hungarian Uprising and the Suez Crisis of 1956 convinced the Yugoslav leadership they should not over-rely on either political bloc. These events coincided with a wave of decolonization in Asia and Africa. As early as July 1956, Josip Broz Tito, together with Gamal Abdel Nasser and Jawaharlal Nehru, signed the Brioni Declaration, considered one of the key initiatives in the creation of the Non-Aligned Movement. This was formalized at the inaugural conference that took place in September 1961, in Belgrade. Yugoslavia now had the opportunity to present its political and economic system, as well as its culture, to the newly independent countries of Africa. Equally wary of their former colonizers and the hegemony of the USSR, African countries provided the Yugoslav leadership with the perfect opportunity to promote the Yugoslav version of socialist self-management and thus contribute to the renown of socialism in the world. One of the most cost-effective ways of promoting Yugoslavia was showcasing its cultural, artistic and historical heritage to African nations through various exhibitions, film screenings, plays and lectures.

In this context, this paper will provide an overview of the more significant guest exhibitions and other cultural events of the African provenance in Belgrade, as well as guest exhibitions by Belgrade artists in certain African countries between 1961 and 1971. These events gradually gave Belgrade the reputation of an intercultural metropolis, culminating in the grand opening of the Museum of African Art in the neighbourhood of Senjak on May $23^{\text {rd }} 1977$.

Key words: Belgrade, Yugoslavia, Africa, the Non-Aligned Movement, cultural exchange, interculturalism, cultural history, the Committee for Cultural Relations of Yugoslavia

\section{$\cos$}

\section{Izvori}

Arhiv Jugoslavije, Beograd, fond 130, Savezno izvršno veće

Arhiv Jugoslavije, Beograd, fond 559, Savezna komisija za kulturne veze s inostranstvom

Arhiv Jugoslavije, Beograd, fond 644, Savez udruženja likovnih umetnika Jugoslavije

Jugoslovenski pregled, 1961. - 1972. 


\section{Katalozi}

4ème Bienalle d'Alexandrie: 14 Décembre 1961 - 31 Mars 1962, katalog izložbe, Aleksandrija 1961. Sème Bienalle d'Alexandrie: 12 Décembre 1963 - 31 Mars 1964, katalog izložbe, Aleksandrija 1963. Ge Bienalle d'Alexandrie: 15 Décembre 1965 - 31 Mars 1966, katalog izložbe, Aleksandrija 1965. L'exposition de Peinture et de Gravure des Jeunes Artistes Yougoslaves, katalog izložbe, Alžir 1970.

\section{Literatura}

Darko BeKIć, Jugoslavija u hladnom ratu: odnosi s velikim silama 1949-1955, Zagreb 1988.

Dušan BIlandžIĆ, Historija Socijalističke Federativne Republike Jugoslavije: glavni procesi 19181985, Zagreb 1985.

Dragan Bogetić, Nova strategija spoljne politike Jugoslavije 1956-1961, Beograd 2006.

Dragan Bogetić i Olivera Bogetić, Nastanak i razvoj pokreta nesvrstanosti, Beograd 1981.

Biserka CvjetičAnin, „Uloga instituta za razvoj i međunarodne odnose u Pokretu nesvrstanih“, Razvojna suradnja kroz nasljede Pokreta nesvrstanih (ur. Gordan Bosanac i Petra Jurlina), Zagreb 2015., 12-39.

Ješa Denegri, „Izložbe inostrane moderne i savremene umetnosti u Srbiji“, Istorija umetnosti u Srbiji XX vek. Drugi tom: Realizmi i modernizmi oko hladnog rata (ur. Miško Šuvaković), Beograd 2012., 375-378.

Branka Doknić, Kulturna politika Jugoslavije 1946-1963, Beograd 2013.

Ivo Goldstein i Slavko Goldstein, Tito, Zagreb 2015.

Tvrtko Jakovina, Treća strana hladnog rata, Zaprešić 2011.

Rinna KullaA, Non-Alignment And Its Origins In Cold War Europe, London - New York 2011.

Kulturna politika i razvitak kulture u Hrvatskoj, Zagreb 1982.

Eyachew Tefera, „Iskustva razvojne suradnje Slovenije iz vremena Pokreta nesvrstanih“, Razvojna suradnja kroz nasljede Pokreta nesvrstanih (ur. Gordan Bosanac i Petra Jurlina), Zagreb 2015., 154-174. 